\title{
Had Economic Reforms had an Impact on India's Industrial Sector?
}

\author{
Dr. Babita Thakur ${ }^{1}$, Vinod Kumar Sharma ${ }^{2}$, Som $_{\text {Raj }}{ }^{3}$
}

\begin{abstract}
India began liberalizing its economy and in particular, it's manufacturing sector over a decade ago with the objective of making Indian Industries more efficient and globally competitive. Towards this end, the Government has been pursuing three sets of reforms:- one, deregulation, delicencing, decontrol and debureaucratisation of industrial licensing system; two, liberalizing foreign trade and currency transactions and three, instituting several measures to facilitate foreign direct investment inflows. All these measures were launched in the year 1991 and since then, further liberalizations have been introduced every year with each new budget. Now the question arises that had economic reforms had an impact on Indian industry? In order to answer this question, we examine trends in industrial production for the period 1950-51 to 1989-90 and 199091 to 2011-12 using the latest available estimates of the Index of Industrial Production (IIP) released by the Central Statistical Organization and Economic Survey, Government of India. The results shows that the decade of 1950's, industrial efficiency was relatively higher; however, in the 1960's and 1970's there was severe retrogression in industrial growth. The period of 1980's was marked by industrial recovery. However, the pattern began reversing themselves in 1990's. But now, particularly after 2002-03, the Indian industry have started showing some signs of improvement in its performance, thus providing some evidence that these reforms seems to be working.
\end{abstract}

\section{Introduction}

Prosperity of any nation is extremely difficult without industrial development - is an well established truth for all the economies - developing or developed. Economic development and industrialization have became so closely integrated with each other that progress of an economy is now accessed from the success it has achieved in transformation from agricultural set up into a industrial set up.

Through industrialization a situation is created whereby many industries are set up rapidly and ultimately backward areas are converted into economically developed areas and backward economies into developed economies. Industrialization, infact is a composite term which involves a number of structural changes such as changes in the production techniques, factor intensities, industrial employment and output. Industrialization propounds support of all sectors of the economy by skillfully organizing business enterprises, application of science and technology, canalizing specialized labour along with the division of labour, ever increasing role of electrical, electronic and computer application to achieve efficient activity etc. In this way industrialization is not only a way to increase output or national income but is a means of introducing modern technology and changing ways of life and finally the structure of the economy because of its self-reinforcing quality.

But the all above cannot be executed without a well planned industrial policy. The industrial polity provides direction to the pace of industrialization and industrial development. Hence, to industrialize the country, India too, framed industrial policy which was amended, modified and reoriented several times.

The First Industrial Policy was framed in 1948, followed by the Industrial Policy Resolution of 1956. The Industrial Policy Resolution of 1956 gave direction to the development of industry till 1973 which resulted in sound base of industrial development in the country. After 1973 the Industrial Policy was amended in 1977 with the objective of accelerating the pace of industrial growth, increasing productivity and income of industrial workers, promoting technological self reliance and increase in the level of employment. After 1977, several amendments were made in the industrial policy but the major landmark change came in 1991 when New Industrial Policy as part of New Economic Policy was introduced.

\section{New Industrial Policy- Salient Features}

The New Industrial Policy of 1991, infact, was a part of structural reforms introduced which was to change the entire outlook towards the industrial development so that Indian industry is made efficient as well as globally competitive. Under atmosphere of economic reforms, broad changes were introduced. The major policy changes initiated in the industrial sector were:- 


\section{Abolition of Industrial licensing}

In a major move to liberalize the economy, all industries except 18 specified industries are exempted from obtaining industrial licensing, irrespective of the level of investment. However, of these 18 industries, now only five industries related to security, strategic or environmental concerns, remain under the purview of industrial licensing. These are :- (i) distillation and brewing of alcoholic drinks; (ii) cigar cigarettes and other substitutes of prepared tobacco; (iii) electronic, aerospace and all types of defence equipment; (iv) industrial explosive including match boxes; and (iv) hazardous chemicals. In case of delicensed industry, no approval is required from the government. However, entrepreneurs are required to submit an Industrial Entrepreneur Memorandum (IEM) to the Secretariat for Industrial Approvals (SIA) which acknowledges receipt.

\section{Policy on Public Sector}

The 1956 Resolution had reserved 17 industries for the public sector. The 1991 industrial policy reduced this number to 8 naming arms and ammunition; atomic energy; coal and lignite; mineral oils; mining of iron ore, manganese ore, chrome ore, gypsum, sulphur, gold and diamond; mining of copper, lead, zinc, tin, molybdenum and wolfarm; minerals specified in the schedule to the atomic energy (control of production and use order), 1953 and rail transport. The policy has been liberalized progressively. Now only three areas are reserved for the public sector naming :- (i) atomic energy; (ii) the substances specified in the schedule to the notification of the Government of India in the Department of Atomic Energy dated the 15 March, 1995; and (iii) railway transport. Recently a decision has been taken to open defence industry sector to private sector with foreign direct investment permissible up to $26 \%$.

\section{Monopolistic and Restrictive Trade Practice limit}

Under the MRTP Act, all firms with assets above a certain size (Rs.100 crore since 1985) were classified as MRTP firms. Such firms were permitted to enter selected industries only and this also on a case by case approval basis. In addition to control through industrial licensing, separate approvals were required by such large firms for any investment proposals. The government felt that this was having a deleterious effect on many large firms in their plans for growth and diversification. The new industrial policy therefore scrapped the threshold limit of assets in respect of MRTP and dominant undertakings. These firms will now be at par with others, and not require prior approval from the government for investment in the delicensed industries. The MRTP Act has been accordingly amended. The now amended Act gives more emphasis to the Prevention and control of monopolistic restrictive and unfair trade practices so that consumers are adequately protected from such practices.

\section{Free entry to foreign investment and technology}

New industrial policy is intended to open up Indian economy to attract foreign investment and technology. Foreigners are allowed to invest in the export oriented industries directly, i.e., foreign equity investment level is raised from 40 percent to 51 percent. Non-resident Indians and overseas corporate bodies are permitted to invest upto 100 percent foreign equity in high priority areas with full benefits of repatriation of capital and income from it.

\section{Industrial Location Policy Liberalized}

In a departure from the earlier locational policy for industries, the new industrial policy provided that in locations other than the cities of more than 1 million population, there will be no requirement of obtaining industrial approvals from the centre, except for the industries subject to compulsory licensing. In cities with the population of more than 1 million, industries other than those of a non-pollution nature were required to be located outside $25 \mathrm{Kms}$ of the periphery. Major amendments were made in the industrial location policy during 1997-98. The requirement of obtaining industrial approvals from the Central government (except for the industries under compulsory licensing) for establishing units at locations not falling with in $25 \mathrm{kms}$ the periphery of cities having a population of more than 1 million was dispensed with. However, notified industries of a non- polluting nature such as electronics, computers software and printing, may be located within $25 \mathrm{kms}$ of the periphery of cities with more than 1 million populations. Other industries are permitted if they are located in designated industrial area set up prior too July 25, 1991. Zoning and Land use Regulations as well as Environment Legislation continue to regulate industrial locations.

\section{Abolition of Phased Manufacturing Programmes for New Projects}

To force the pace of indigenization in manufacturing, Phased Manufacturing Programmes have been in force in a number of engineering and electronic industries. The new industrial policy abolished such programmes for future as the government felt that due to substantial reforms made in the trade policy and the devaluation of the rupee, there was no need for enforcing the local content requirements on a case-by-case, 
administrative basis. Various incentives that are currently available to manufacturing units with existing Phased Manufacturing Programmes were to continue.

\section{Removal of Mandatory Convertible Clause}

Since large part of industrial investment in India is financed by loans from banks and financial institutions, hence these institutions followed a mandatory practice of including a convertibility clause in their lending operation for new projects. This provided them an option of converting part of their loans into equity if felt necessary by their management. This has been interpreted as an unwarranted threat to the private firms to be taken over by the financial institutions. The new industrial policy provided that hence forth financial institutions will not impose this mandatory convertibility clause.

\section{Pre-Reform Decade}

\section{Performance Of Industrial Sector}

Index numbers of industrial production during 1951 to 1980 are shown in Table 1.

Table 1

Annual Compound Growth Rates in Index Numbers of Industrial Production, 1951 to 1980 (Use Based) (Base 1980-81=100) per cent per annum

\begin{tabular}{|l|l|l|l|l|l|l|}
\hline $\begin{array}{l}\text { Use Based or Functional } \\
\text { Classification }\end{array}$ & $\begin{array}{l}\mathbf{1 9 5 1}- \\
\mathbf{1 9 5 5} \\
\mathbf{4} \text { Years) }\end{array}$ & $\begin{array}{l}\mathbf{1 9 5 5}- \\
\mathbf{1 9 6 0}\end{array}$ & $\begin{array}{l}\mathbf{1 9 6 0} \\
\mathbf{1 9 6 5}\end{array}$ & $\mathbf{1 9 6 5 - 1 9 7 6}$ & $\begin{array}{l}\mathbf{1 9 7 6}-\mathbf{1 9 7 9} \\
\text { ( Fifth Plan } \\
\text { Average) }\end{array}$ & $\begin{array}{l}\mathbf{1 9 7 9} \\
\mathbf{1 9 8 0}\end{array}$ \\
\hline 1.Basic Goods & 4.7 & 12.1 & 10.4 & 6.5 & 8.4 & -0.5 \\
2.Capital Goods & 9.8 & 13.1 & 19.6 & 2.6 & 5.7 & -2.3 \\
3.Intermediate Goods & 7.8 & 6.3 & 6.9 & 3.0 & 4.3 & 1.9 \\
4. Consumer Goods & 4.8 & 4.4 & 4.9 & 3.4 & 5.5 & -4.4 \\
(a) Durable & - & - & - & 6.2 & 6.8 & 5.6 \\
(b) Non-durable & - & - & - & 2.8 & 5.4 & -6.1 \\
\hline General Index & 5.7 & 7.2 & 9.0 & 4.1 & 6.1 & -1.6 \\
\hline
\end{tabular}

Source:-

1) S.L.Shetty, Structural Retrogression in the Indian Economy since the Mid-1960s, Economic and Political Weekly, Special Supplement, 1978, Table 4, p.9

2) Government of India, Hand Book of Industrial Statistics, 1992, Table 50, p.155 and Table 54, p.155.

The Table 1 shows that the compound (annual) rate of industrial production has shown a noticeable acceleration from 5.7 percent in the First Plan to 7.2 percent in the Second Plan and further to 9.0 percent in the Third Plan. The period 1965 to 1976 was marked by a sharp deceleration in industrial growth. The rate of growth which was 9.0 percent in the third plan fell steeply to 4.1 percent per annum during 1965 to 1976. However, industrial growth picked up slightly to 6.1 percent in 1976 to 1979 but the year 1979-80 recorded a negative growth rate of industrial production of -1.6 percent.

The basic goods industries registered a significant increase from 4.7 percent per annum in the First Plan to 12.1 percent per annum in the Second Plan and stood at 10.4 percent in the Third Plan. However, the rate of growth of basic goods industries over the eleven year period 1965 to 1976 declines to 6.5 percent per annum. Then in 1976 to 1979 it registered a slight increase to 8.4 percent per annum but fell sharply in the next year and recorded a negative growth rate of -0.5 percent per annum in 1979-80.

The rate of growth of capital goods industries shot up considerably from 9.8 percent per annum in the First Plan to 13.1 percent per annum in the Second Plan and further to 19.6 percent per annum in the Third Plan. . However, in the next eleven years 1965 to 1976, it grew at an annual rate of only 2.6 percent. In the Fifth Plan period, the rate of growth of capital industries goes up to 5.7 percent per annum but in 1979-80 it registered a negative growth rate of -2.3 per cent per annum.

The rate of growth in the intermediate goods was 7.8 percent per annum during the First Plan but it fell to 6.3 per cent per annum in the Second Plan. The rate of growth in the intermediate goods industries goes up to 6.9 per cent per annum in 1960-65 but fell to only 3.0 per cent per annum in 1965-76. In 1976-99 the rate of growth of intermediate goods industries registered a small increase to 4.3 per cent per annum over the preceding year. The year 1979-80, recorded a negative growth rate of -4.4 per cent per annum. The same story is found in the case of consumer goods industries.

It becomes clear from the table 1 that during the first three plan periods a strong base for industrial development laid. But the period 1965 to 1980 was marked by a sharp deceleration in industrial growth. Decline in the rate of growth of capital goods industries, basic goods industries, intermediate goods industries and consumer goods industries both durable goods as well as non-durable goods industries after the third plan represents the phenomenon of deceleration and retrogression. The wars of 1965 and 1971, drought conditions in 
some years, infrastructural constraints and bottlenecks, and the oil crisis of 1973 were considered as responsible for slow down of industrial growth.

\section{Back on the track}

The period of 1980s can be broadly be termed as a period of industrial recovery as becomes clear by a study of the revised Index of Industrial Production (base 1980-81=100) shown in Table 2. As is clear from the figures given in the Table 2, the rate of industrial growth was 6.4 percent per annum during 1981-85 which went up to 8.5 per cent per annum during Seventh plan and then came down to 8.3 per cent per annum in 1990-91.

The rate of growth of capital goods industries registered an significant increase from 6.2 percent per annum in 1981-85 to 14.8 per cent per annum in 1985-90 and further to 17.4 per cent per annum in 1990-01.

Table 2

Annual Compound Growth Rates in Index Numbers of Industrial Production, 1981 to 1991 (Use Based) (Base 1980-81=100) Per cent per annum

\begin{tabular}{|l|l|l|l|}
\hline $\begin{array}{l}\text { Use Based or Functional } \\
\text { Classification }\end{array}$ & $\mathbf{1 9 8 1} \mathbf{- 1 9 8 5}$ & $\mathbf{1 9 8 5 - 1 9 9 0}$ & $\mathbf{1 9 9 0} \mathbf{- 1 9 9 1}$ \\
\hline 1.Basic Goods & 8.7 & 7.4 & 3.8 \\
2.Capital Goods & 6.2 & 14.8 & 17.4 \\
3.Intermediate Goods & 6.0 & 6.4 & 6.1 \\
4. Consumer Goods & 5.1 & 7.3 & 10.4 \\
(a) Durable & 14.3 & 11.6 & 14.8 \\
(b) Non-durable & 3.8 & 6.4 & 9.4 \\
\hline General Index & 6.4 & 8.5 & 8.3 \\
\hline
\end{tabular}

Source: - Computed from Government of India, Hand Book of Industrial Statistics, 1992, Table 50, p.50 and Table 54, p.155.

The rate of growth of consumer goods industries also registered an increase from 5.1 percent per annum in 1981-85 to 7.3 per cent per annum in 1985-90 and further to 10.4 per cent per annum in 1990-91.

The growth of basic goods industries decelerate from 8.7 percent per annum in 1980-85 to 7.4 per cent per annum in 1985-90. However, in the next year rate of growth of this sector fell steeply to mere 3.8 per cent per annum in 1990-91.

The rates of growth of intermediate goods industries have shown fluctuations. The rate of growth of intermediate goods industries registered an increase from 6.0 percent per annum in 1980-85 to 6.4 per cent per annum in 1985-90 but then it fell to 6.1 per cent per annum in 1990-91.

As a whole we can say that the growth rate of industrial production, which registered a negative growth rate of -1.6 per cent per annum in 1979-80 showed a marked improvement in the period of 1980s.

\section{Post-Reform Decade}

Index numbers of industrial production during 1990-94 are shown in Table 3. The index of industrial production was 212.6 in 1990-91 and was stagnant in the next year. Obviously, this was due to the dismal performance of the manufacturing sector in 1991-92 mainly due to severe import compression. It is reported that 10 major industry groups with a weight of 30 per cent in the total weight of 77.75 per cent of the manufacturing sector, suffered a decline in production. Further, many major industries, except a few, recorded a slower growth; export industries suffered a recession and the industrial demand declined significantly due to the collapse of the Soviet political system. On the other hand, the mining and quarrying industry managed to improve its industrial production marginally while the production index of electricity showed a significant rise of 8.5 per cent in 199192. In all, within a short period of nine months from the date of announcement of the New Industrial Policy the slipping down position of the industrial sector was revived and placed on the track of progress and the same status was maintained with the General Industrial Production remaining almost stagnant at 213.9 in 1991-92.

Table 3

Index Numbers of Industrial Production,

1991 to 1994 (Use Based) (Base 1980-81=100)

\begin{tabular}{|l|l|l|l|l|}
\hline Indicator & $\mathbf{1 9 9 0 - 9 1}$ & $\mathbf{1 9 9 1 - 9 2}$ & $\mathbf{1 9 9 2 - 9 3}$ & $\mathbf{1 9 9 3 - 9 4}$ Estimates \\
\hline Index of Industrial Production & $212.6(8.2)$ & $213.9(0.6)$ & $218.9(2.3)$ & $227.8(4.5)$ \\
Manufacturing & $207.8(9.0)$ & $206.2(-0.8)$ & $210.7(2.2)$ & $218.3(3.6)$ \\
Mining and quarrying & $221.2(4.5)$ & $222.5(0.6)$ & $223.9(0.6)$ & $229.4(2.5)$ \\
Electricity & $236.8(7.8)$ & $257.0(8.5)$ & $269.9(5.0)$ & $288.8(7.0)$ \\
\hline
\end{tabular}

Figures in the brackets indicate percentage change over the precious year.

Source: - Economic Survey 1994-95. 
The favorable impact of the New Industrial Policy can be cognized from the positive growth of indices of all indicators presented in the table 3 for the year 1992-93. The depressed conditions of 1991-92 of the manufacturing sector are reversed and a positive growth of 2.2 per cent was recorded in the next year. Eightysix industries with weight of 54.7 per cent out of 88.10 per cent showed a positive growth rate and 47 industries with a weight of 13.7 per cent showed a rise of over 10 per cent. Cement, machinery, wrist-watches, shipbuilding, sugar, cloth, polyester, railway wagons, etc recorded a growth rate of over 10 per cent.

The general index of industrial production changed by 2.3 per cent in $1992-93$ over the preceding year because the intermediate goods, capital goods, consumer durables and basic industries achieved a positive growth. The mining and quarrying industrial sector also registered the same rate of growth while the growth rate of electricity sector was positive (5\%) but less than the previous year. Table 3 also shows that the general index of industrial production would be 4.5 percent while that of the electricity sector would be 7 percent in 1993-94.

The entire post reform period has been marked by considerable yearly fluctuations. However, the growth in the industrial sector in 2006-07 continued to be healthy. The Index of Industrial Production (IIP) grew by 11.6 percent (Table 4). The major element of the buoyancy in industrial growth was the manufacturing sector with 80 percent weight in Index of Industrial Production. Manufacturing witnessed growth of 12.5 percent, while mining and electricity grew by 5.4 percent and 7.2 percent respectively.

Table 4

Annual growth rate of industrial production in major sectors of industries (Based on the index of industrial production)

Base 1993-94=100

(Percent)

\begin{tabular}{|l|l|l|l|l|}
\hline Period & Mining \& Quarrying & Manufacturing & Electricity & Over all \\
\hline Weight & 10.47 & 79.36 & 10.17 & 100.00 \\
$1994-95$ & 9.8 & 9.1 & 8.5 & 9.1 \\
$1995-96$ & 9.7 & 14.1 & 8.1 & 13.0 \\
$1996-97$ & -1.9 & 7.3 & 4.0 & 6.1 \\
$1997-98$ & 6.9 & 6.7 & 6.6 & 6.7 \\
$1998-99$ & -0.8 & 4.4 & 6.5 & 4.1 \\
$1999-00$ & 1.0 & 7.1 & 7.3 & 6.7 \\
$2000-01$ & 2.8 & 5.3 & 4.0 & 5.0 \\
$2001-02$ & 1.2 & 2.9 & 3.1 & 2.7 \\
$2002-03$ & 5.8 & 6.0 & 3.2 & 5.7 \\
$2003-04$ & 5.2 & 7.4 & 5.1 & 7.0 \\
$2004-05$ & 4.4 & 9.2 & 5.2 & 8.4 \\
$2005-06$ & 1.0 & 9.1 & 5.2 & 8.2 \\
$2006-07$ & 5.4 & 12.5 & 7.2 & 11.6 \\
$2007-08$ (April & 4.4 & 12.2 & 7.5 & 11.2 \\
- Dec) & & & & \\
\hline
\end{tabular}

Source: - Central Statistical Organization.

The consumer durable sector (refrigerators, electric fans, television, motor cycles and cars) witnessed a complete turn around. It grew by 11.6 percent (Table 5) during

Table 5

Growth Rates of Industrial Production by use-based classification

(Base 1993-94=100) per cent per annum

\begin{tabular}{|l|l|l|l|l|l|l|l|l|l|l|}
\hline Sectors & Weight & $\begin{array}{l}1997- \\
98\end{array}$ & $\begin{array}{l}1999- \\
00\end{array}$ & $\begin{array}{l}2000- \\
01\end{array}$ & $\begin{array}{l}2001- \\
02 \\
(2)\end{array}$ & $\begin{array}{l}2002- \\
(3)\end{array}$ & $\begin{array}{l}2003- \\
(4) \\
(1)\end{array}$ & $\begin{array}{l}2004- \\
(8)\end{array}$ & $\begin{array}{l}2005- \\
(9)\end{array}$ & $\begin{array}{l}2006- \\
(10)\end{array}$ \\
$(1)$ & $(11)$ \\
\hline $\begin{array}{l}\text { Basic } \\
\text { Goods }\end{array}$ & 35.6 & 6.9 & 5.5 & 3.7 & 2.6 & 4.9 & 5.4 & 5.5 & 6.7 & 10.3 \\
\hline $\begin{array}{l}\text { Capital } \\
\text { Goods }\end{array}$ & 9.3 & 5.8 & 6.9 & 1.8 & -3.4 & 10.5 & 13.6 & 13.9 & 15.8 & 18.2 \\
\hline $\begin{array}{l}\text { Intermed- } \\
\text { iate } \\
\text { Goods }\end{array}$ & 26.5 & 8.0 & 8.8 & 4.7 & 1.5 & 3.9 & 6.4 & 6.1 & 2.5 & 12.0 \\
\hline $\begin{array}{l}\text { Consumer } \\
\text { Goods }\end{array}$ & 28.7 & 5.5 & 5.7 & 8.0 & 6.0 & 7.1 & 7.1 & 11.7 & 12.0 & 10.1 \\
\hline Consumer & 5.4 & 7.8 & 14.1 & 14.5 & 11.5 & -6.3 & 11.6 & 14.4 & 15.3 & 9.2 \\
\hline
\end{tabular}


Had Economic Reforms had an Impact on India's Industrial Sector?

\begin{tabular}{|c|c|c|c|c|c|c|c|c|c|c|}
\hline Durables & & & & & & & & & & \\
\hline $\begin{array}{l}\text { Consumer } \\
\text { Non- } \\
\text { Durables }\end{array}$ & 23.3 & 4.8 & 3.2 & 5.8 & 4.1 & 12.0 & 5.8 & 10.8 & 11.0 & 10.4 \\
\hline $\begin{array}{l}\text { IIP } \\
\text { (Index Of } \\
\text { Industrial } \\
\text { Production) }\end{array}$ & 100 & 6.7 & 6.7 & 5.0 & 2.7 & 5.7 & 7.0 & 8.4 & 8.2 & 11.6 \\
\hline
\end{tabular}

\section{Source: -}

(i) Data for column (3) \& (4) are from Reserve Bank of India, Hand Book of Statistics on Indian Economy, 2000 (Mumbai, 2000), Table 199, p.409 \& Table 200, p.410;

(ii) For column (5), (6), (7), (8), (9) \& (10), Government of India, Economic Survey, 2006-07, Table 7.2, p.137; and

(iii) For column (11), Central Statistcal Organization, IIP, 12 Feb 2008.

2003-04 compared from a decline of -6.3 percent during the previous year. Lower interest rates, the availability of retail finance and the strong monsoon are among the explanations for this sharp growth in the consumer durable sector. Then in 2005-06, the sector registered a further increase to 15.3 percent but fell sharply to 9.2 percent in the very next year.

The growth in the consumer non-durables fell sharply in 2003-04 to 5.8 percent whereas, in 2002-03 the sector grew at 12.0 per cent. Fast moving Consumer Goods (FMCG) Companies did not perform well as price wars cut into profit margins. Competition from local bands and inadequate coverage of IIP were the explanation for the poor performance of consumer non-durables. In 2004-05, the sector registered an increase to 10.8 percent and further to 11.0 percent in 2005-06 but fell to 10.4 percent in 2006-07.

The basic goods industries and intermediate goods industries registered a sharp increase from 6.7 percent and 2.5 percent in 2005-06 to 10.3 percent and 12.0 percent in 2006-07.

Growth in the capital goods industries sector was also healthy. Production in this sector increased from 10.5 percent in 2002-03 to 13.9 percent in 2004-05 and further to 18.2 percent in 2006-07. The above examples of yearly growth rates during the post- reform period show that the different sectors have registered marked upheavals over the years. Thus there is a total lack of consistency in industrial performance. As a clear from Table 6, the over all rate of growth of industrial production in the year 2001-02 was only 2.7 percent. Table shows that, the industrial performance improved during the first five years of the Tenth Plan - from 5.7 percent in 2002-03 to 8.4 percent in 2004-05 and further to 11.6 percent in 2006-07.

According to the quick estimates of the Index of Industrial Production (IIP) released by CSO on February 12, 2008, the cumulative industrial growth for nine months (April - December 2007) has slipped down to 9 percent from 11.6 percent obtained during the same period of 2006-07. The nine months growth rate of manufacturing sector declined to 9.6 percent from 12.2 percent in the previous fiscal. Similarly, the growth rates for mining and electricity sectors worked out to be 4.9 percent and 6.6 percent respectively, compared to 4.4 percent and 7.5 percent during the corresponding period of 2006-07.

As per released data, the industrial growth slipped to 7.6 percent in December 2007 from 13.4 percent in the corresponding month of 2006 an account of widespread deceleration in manufacturing, mining and electricity. The slippage in industrial output growth in December 2007 can be attributed mainly to manufacturing, which decelerated to 8.4 percent from 14.5 percent in the corresponding month of 2006. Mining and electricity also performed poorly during the month, recording growth rates of 3 percent and 3.8 percent respectively against percent and percent in December 2006.Consumer goods, in addition to other segments of the industry like basic goods and capital goods, also saw slowing growth during December 2007.

Infrastructure industries recorded a cumulative growth of 5.5 percent during April- January 2007- 08 compared to the 8.9 percent growth recorded during the first ten months of fiscal 2006-07. In January 2008 the six infrastructure industries - coal, power, cement, finished steel, crude petroleum and petro refinery products with a collective weight of 26.7 percent in the industrial production index - recorded a growth of 4.2 percent compared to the 8.3 percent recorded in January 2007. Showing marked signs of recovery from the lows in the previous two months, industrial growth inched up to 7.1 per cent in July this year on account of an upswing mainly in two sectors - capital goods and consumer durables. The data on the Index of Industrial Production (IIP) released by the Central Statistical Organization (CSO) revealed that the 7.1 percent over all growth achieved during the month was lower as compared to the 8.3 per cent increase witnessed in July 2007. However, even at this level, the heartening signal was that industrial production, at slightly above the seven per cent increase notched up in April, appeared to be back on the recovery path from the low growth of 3.8 percent in May and 5.4 percent in June. Aiding the industrial recovery was the huge growth in capital goods production which surged by a steep 21.9 per cent from 12.3 percent July last year. 
The Graph 1 showing percentage change in India's Industrial Production during 2002 to 2012 (given below) very clearly reveals that from 1994 until 2010, India's industrial production averaged 7.49 percent reaching an historical high of 17.70 percent in December, 2009.

\section{Graph 1}

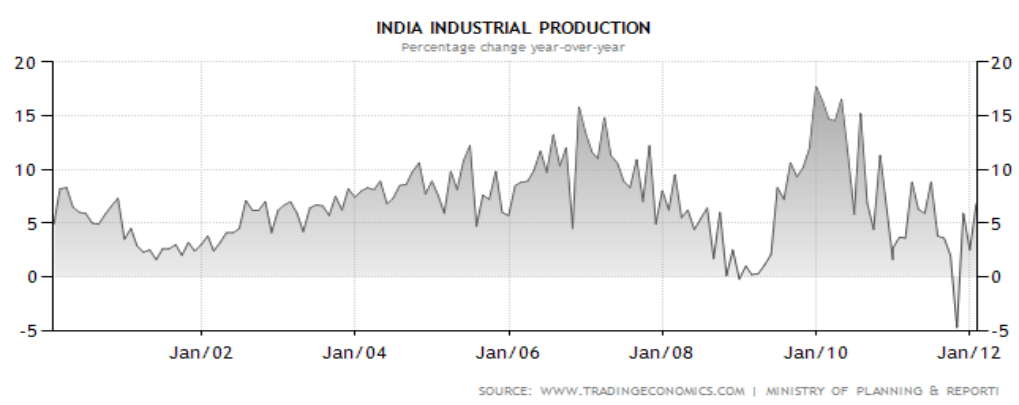

However, the growth in Index of Industrial Production (IIP) came down from 10.5 percent level in the year 2009-10 to 7.8 percent in 2010-11. This fall was mainly due to poor performance of the manufacturing and mining sectors. The manufacturing sector, registered its annual growth fall to 8.1 percent in 2010-11 from 11 percent in 2009-10. The mining sector also saw a decline in growth to 5.9 percent in 2010-11 from 9.9 percent of 2009-10. The growth of electricity sector slowed to 5.6 percent in 2010-11 from 6 percent in 2009-10. But production in the consumer non-durables segment went up by 2.2 percent in 2010-11 as against 0.4 percent in 2009-10. Overall, consumer goods output reported a rise of 7.5 percent in 2010-11 as against 6.2 percent in 2009-10. Intermediate goods segment also registered a rise from 13.6 percent in 2009-10 to 8.8 percent in 201011.

In May 2012, the eight core sectors industries registered 3.8 percent growth, which was mainly due to improved production of coal and cement. Core sector industries grew higher at 5.8 per cent in May 2012. The April figure for the core sector was revised upwards from 2.2 percent to 3.9 percent. Index of Industrial Production (IIP) had recorded a growth of just 0.1 per cent in April. For the first two months of 2012-13, the eight core sectors grew 3.4 per cent, virsus five per cent in 2011-12. Coal output grow 8 per cent in May as against 3.8 per cent in April, which may reflect in the mining in IIP that has been contraction since August 2011, barring February 2012. Coal production recorded a growth of 5.9 per cent in the first two months of FY 13 compared to 2.0 per cent during the same period in 2011-12.

\section{Conclusion}

From the above discussion it can be concluded that relative to the past industrial performances, the Economic reforms that have taken place in India in 1991 and thereafter have started showing positive impact on current Indian industrial performance in the last few years. In the light of increasing level of productivity as a result of economic reforms, one can hope for a reasonable rate of growth of industrial sector in the coming years.

\section{References}

[1] A Hand Book of Industrial Statistics; Government of India; 1992; p.50 \& 155

[2] A Hand Book of Statistics on Indian Economy; Mumbai; 2000; p.409 \& 410.

[3] Central Statistical Organization; IIP; 12 Feb. 2008.

[4] Current Status of Industrial Production; Pratiyogita Darpan; Delhi; June 2012.

[5] Ghosh Alak, New Look Industrial Policy, New Economic Reforms and the Eighth Five Year Plan, Indian Economy its nature and problems, New Stall Publishers; Calcutta; January, 1994, p.125-127.

[6] State Economy; Economic Survey Highlights; Yojana 15; April 1992; Vol 36; p.10-12.

[7] Economic Scenario, Pratiyogita Darpan, August-September 2012, p. 238.

[8] Economic Survey - 1989-99.

[9] Economic Survey - 2001-02.

[10] Economic Survey - 2006-07.

[11] Industrial growth recovers; Chanakya; November 2008; p.38.

[12] Industrial Revival Sustained; the Hindu; March 5, 1994.

[13] Janathan E. Hasket, Sania C. Pereira, \& Mathew J. Slaughte; Does Inward Foreign Investment Boost the productivity of Domestic Firms?; The Review of Economics and Statistics; August 2007; Vol. LXXXIX; 89 (3); pp. 482-496.

[14] Major Reforms in Customs and Tariff Structure in Budget 1994-95; the Hindu; March1, 1994.

[15] Ministry of Finance; Economic Division; Economic Survey of India; 1992-93.

[16] Munjal Poonam; Structural Changes in Indian Economy: An Input- Output Analysis; Indian Economic Review; Delhi School of Economics; January- June 2007; Vol. XXXXII; November 1; pp.77-95.

[17] Prof Rao k. Nageswara and T.S.P.Venkateswar Raju; New industrial policy and industrial progress; Kurukshetra; March 1996, p. 15-17.

[18] Rao, A.N. (1991); New Industrial Policy; Yojana 1-15 September; September 9.

[19] Reddy, Lata Arun; India's New Industrial Policy: A view; 1993; Asian Economic Review; p.46-50.

[20] Shetty, S.L.; Structural Retrogression in the Indian Economy since the Mid-1960s; Economic and Political Weekly; 1978; Table 4; p.9. 